\title{
The Costs and Benefits of Letting Juries Punish Corporations: Comment on Viscusi
}

\author{
Robert J. MacCoun*
}

On the basis of a new survey-administered mock juror experiment, Kip Viscusi suggests that a corporate defendant "[u]ndertaking even a sound risk analysis in line with that used by government regulators" actually increases the magnitude of punitive damage verdicts, even when the corporation's analysis "may have struck an appropriate risk-cost balance." 1 This finding should not surprise us in light of the tremendous controversy that followed the revelation that on the basis of a benefit-cost analysis, the Ford Motor Company decided against an eleven dollar safety alteration in each Ford Pinto, despite their anticipation that this could prevent almost two hundred burn deaths. ${ }^{2}$

Thus, for the purposes of this brief comment I take Viscusi's empirical findings - in particular, the finding that punitive awards were larger in the versions of the case where a corporate risk analysis was conducted-at face value, and grant for the sake of argument that they might describe actual juror judgments in similar cases, absent any countervailing influences at trial. ${ }^{3}$

* Jurisprudence and Social Policy Program, School of Law (Boalt Hall), and Goldman School of Public Policy, University of California at Berkeley. Email: maccoun@socrates.berkeley. edu. (2000).

1. W. Kip Viscusi, Corporate Risk Analysis: A Reckless Act?, 52 STAN. L. REV. 547, 552

2. See Mark Dowie, Pinto Madness, MOTHER JONES, Sept.-Oct. 1977, at 18. Indeed, I've found that the Pinto case makes an excellent didactic device for classroom discussions on regulatory policy, because it so reliably elicits student outrage.

3. The fact that Viscusi's stimulus materials are brief and artificial is not in and of itself an inherent flaw; artificiality can be a virtue in theory-testing research, so long as one uses mock juror surveys to identify effects rather than to estimate their magnitudes. For a more detailed discussion, see Robert MacCoun, Inside the Black Box: What Empirical Research Tells Us About Decisionmaking by Civil Juries, in VERDICT: ASSESSING THE CIVIL JURY SYSTEM 137-80 (Robert E. Litan ed., 1993). The important question is whether there are strong reasons to believe that a less artificial judgment setting would have led to different results. In this particular case, it is conceivable that the defense lawyers, their experts, and/or the judge would provide information at trial that would help jurors appreciate the rationale for corporate risk analysis. Also, if Viscusi is correct in the assertion that his results are a manifestation of hindsight bias, jury deliberation might well have attenuated the results, since there is some evidence that groups are less susceptible than individuals to this bias. See generally Dagmar Stahlberg, Frank Eller, Anne Maass \& Dieter Frey, We Knew It 
Instead, in this brief comment I discuss the need to disentangle several plausible explanations for his results (which are not mutually exclusive) and their implications for legal policy. Some support Viscusi's contention that the punitive awards process is vulnerable to systematic cognitive bias; others suggest a more fundamental clash of values between the normative framework of risk analysis and lay intuitions of justice and blameworthiness.

\section{HINDSIGHT BIAS}

Viscusi suggests that his findings are yet another manifestation of a hindsight bias in legal judgment. 5 In brief, the hindsight bias is the tendency to overestimate the ex ante predictability of an outcome, after one learns it has already occurred; it is the exaggerated sense that one did (or would have) "known it all along."6 Recent experiments have implicated the hindsight bias in citizens' ex post evaluations of police searches, criminal verdicts, and negligence and punitive damage judgments in tort litigation.7

If in fact the hindsight bias explains Viscusi's results-in the sense that they reflect an artifact of ex post judgment-it is not clear how we might mitigate the effect. Laboratory attempts to "debias" ex post judgments have been mostly unsuccessful, and prospects for debiasing at trial aren't encouraging; 8 although there is some evidence that the defense can reduce hindsight

All Along: Hindsight Bias in Groups, 63 ORg. BeHAV. \& HUM. DeCISION PROCEsses 46 (1995) (discussing the results of two studies comparing the occurrence of hindsight distortion in groups with that of individuals).

4. See Viscusi, supra note 1 , at $570,587$.

5. See id. For a detailed examination of hindsight bias in legal factfinding, see Jeffrey J. Rachlinski, A Positive Psychological Theory of Judging in Hindsight, 65 U. CHI. L. REV. 571 (1998) (explaining the concept of hindsight bias and how the law reflects this bias).

6. Psychological research on the hindsight bias is reviewed by Jay J.J. Christensen-Szalanski \& Cynthia Fobian Willham, The Hindsight Bias: A Meta-Analysis, 48 ORG. BEHAV. \& HUM. DECISION PROCESSES 147 (1991), and Scott A. Hawkins \& Reid Hastie, Hindsight: Biased Judgments of Past Events After the Outcomes Are Known, 107 PsYCHOL. BULL. 311 (1990).

7. The pioneering study on hindsight in legal judgments is Jonathan D. Casper, Kennette Benedict \& Jo L. Perry, Juror Decision Making, Attitudes, and the Hindsight Bias, 13 LAW \& HuM. BEHAV. 291 (1989). Other recent studies include Reid Hastie, David A. Schkade \& John W. Payne, Juror Judgments in Civil Cases: Hindsight Effects on Judgments of Liability for Punitive Damages, 23 LAW \& HUM. BEHAV. 597 (1999); Reid Hastie \& W. Kip Viscusi, What Juries Can't Do Well: The Jury's Performance as a Risk Manager, 40 ARIZ. L. REV. 901 (1998); Kim A. Kamin \& Jeffrey J. Rachlinski, Ex Post $\neq$ Ex Ante: Determining Liability in Hindsight, 19 LAW \& HUM. BEHAV. 89 (1995); Susan J. LaBine \& Gary LaBine, Determinations of Negligence and the Hindsight Bias, 20 LAW \& HUM. BEHAV. 501 (1996); Jennifer K. Robbennolt \& Mark S. Sobus, An Integration of Hindsight Bias and Counterfactual Thinking: Decision-Making and Drug Courier Profiles, 21 LAW \& HUM. BEHAV. 539 (1997).

8. See Kamin \& Rachlinski, supra note 7, at 99 (concluding that judicial debiasing instructions failed to reduce hindsight bias); Rachlinski, supra note 5, at 603-05 (dismissing debiasing jury instructions and suppressing evidence as ineffectual means of counteracting the hindsight bias). $C f$. Hal R. Arkes, Principles in Judgment/Decision Making Research Pertinent to Legal Proceedings, 7 BEHAV. SCI. \& L. 429, 450-51 (1989) (stating that the "consider the opposite" technique, which 
bias during closing arguments. 9 Instead, Viscusi's preferred solution is to curtail greatly the jury's involvement in punitive and other civil judgments. ${ }^{10}$ The most likely alternative is the bench verdict. In an earlier paper, Viscusi and coauthor Reid Hastie present evidence suggesting that judges are less susceptible than juries to hindsight bias. 11 But at least two studies have demonstrated hindsight bias in judgments by professional judges, 12 and there are three reasons to doubt the claim that they are less vulnerable than juries. First, simulation experiments of this sort are suitable for demonstrating the existence of a judgment bias, but inappropriate for estimating its magnitude in actual trials. Second, Richard Lempert argues that the Hastie and Viscusi data, considered in their entirety, actually show roughly comparable hindsight biases for judges and jurors, once various methodological differences between the judge and juror research protocols are taken into consideration..$^{13}$ And third, all three studies compare judges to individual jurors, not juries, yet groups have been shown to be somewhat less susceptible than individuals to hindsight bias. ${ }^{14}$ If so, any slight advantage of judges over individual jurors might be offset by deliberation. 15

But at the risk of sounding academically territorial, it is not clear that Viscusi's results are due to hindsight bias as psychologists use the term. Viscusi argues that ex post, jurors compare the value of the human life that was lost in the accident to the relatively trivial amount that could have been spent making a safety improvement for the particular vehicle in the accident.16 Viscusi presents no direct evidence that his respondents made such a

requires jurors to find reasons for alternative conclusions before reaching a decision, is an effective way of reducing hindsight bias); David B. Wexler \& Robert F. Schopp, How and When to Correct for Juror Hindsight Bias in Mental Health Malpractice Litigation: Some Preliminary Observations, 7 BEHAV. SCI. \& L. 485, 490-91 (1989).

9. See Merrie Jo Stallard \& Debra L. Worthington, Reducing the Hindsight Bias Utilizing Attorney Closing Arguments, 22 LAW \& HUM. BEHAV. 671, 680-81 (1998) (discussing how hindsight bias was reduced where mock jurors viewed three different versions of plaintiff and defense counsels' closing arguments, including one incorporating a hindsight debiasing strategy).

10. See Viscusi, supra note 1, at 552 ("More sweeping legal reforms, such as proposals to take punitive damages out of the hands of jurors or to abolish punitive damages altogether for corporate risk decisions, are needed.").

11. See Hastie \& Viscusi, supra note 7.

12. Rachlinski, supra note 5 , at 580.

13. See Richard Lempert, Juries, Hindsight, and Punitive Damage Awards: Failures of a Social Science Case for Change, 48 DEPAUL L. REV. 883, 884-86 (1999).

14. See note 3 supra.

15. But a more comprehensive mathematical analysis suggests that group deliberation can either amplify or attenuate such biases, depending on various other features of the task. See Norbert L. Kerr, Robert J. MacCoun \& Geoffrey Kramer, Bias in Judgment: Comparing Individuals and Groups, 103 PsYCHOL. REv. 687 (1996) (describing a model which reveals that the relative magnitude of individual and group bias depends on several factors, including group size, initial individual judgement, the magnitude of bias among individuals, the type of bias, and the group judgement process).

16. See Viscusi, supra note 1 , at 563. 
comparison, but the hypothesis is plausible, and such a comparison would indeed be misleading, unreasonable, and unfair to the defendant. But this isn't the same "hindsight bias" that was examined in those studies claiming that hindsight bias is difficult to debias. ${ }^{17}$ Strictly speaking, the hindsight bias occurs when, after learning of an outcome, one overestimates the probability one would have assigned to that outcome ex ante.18 Operationally, a hindsight bias is demonstrated by comparing the likelihood judgments of perceivers before versus after receiving outcome information. But in Viscusi's experiment, the outcome was held constant, available to all of his participants. And he presents no evidence that his respondents in the risk analysis conditions perceived a greater accident probability than those in the control conditions.

What Viscusi did vary was the basis for the corporate decision to forego extra spending on safety measures: specifically, whether or not a benefit-cost analysis was conducted, and the inputs that were used in that analysis. Imagine Viscusi had crossed his "risk analysis" manipulation with a second manipulation varying whether jurors evaluated the corporate behavior with or without knowing that the accident occurred. In the jargon of experimental design, we know from Viscusi's actual experiment that there is a "main effect" for the first variable (risk analysis vs. no risk analysis), and we know from previous studies that there is a main effect for the second (ex ante vs. ex post) variable - a hindsight bias. Rather than a hindsight bias, Viscusi's interpretation of his results seems to imply an interaction of these two factors, such that the risk analysis factor only matters when judgments are made ex post. But other interpretations discussed below would imply that the factors are simply additive, i.e., that hindsight bias and Viscusi's effect have nothing to do with each other.

Viscusi's explanation, if correct, would be similar to hindsight bias in that the action (risk analysis) would seem more reasonable ex ante than ex post. But the difference between his account and hindsight bias isn't just academic nitpicking. Prior evidence on the difficulty of debiasing the effect of outcome knowledge on event probability judgments isn't directly relevant. Instead, we need to tell jurors to evaluate the ex ante estimated costs versus benefits of safety improvements on the same per-vehicle basis, rather than comparing the small average safety cost to the horrible loss of life for the particular vehicle in the case at issue. Viscusi offered his respondents no such admonishment, but presumably a competent defense attorney would (or could) attempt to do so. Whether that would be effective is still an open question.

17. See Rachlinski, supra note 5 , at 586-87.

18. See Hawkins \& Hastie, supra note 6, at 311 ("The hindsight bias is the tendency for people with outcome knowledge to believe falsely that they would have predicted the reported outcome of an event."). 


\section{FORESEEABILITY, INTENT, AND TABOO TRADEOFFS}

An alternative possibility is that a cognitive misperception account is either wrong or unnecessary to explain his results. Perhaps participants viewed the evidence of a corporate risk analysis as clear evidence that the defendant both foresaw the possibility of serious injury and proceeded intentionally despite that knowledge. Viscusi's paper is quite sketchy about his instructions to participants; e.g., it is not clear whether jurors received standard patterned jury instructions defining the relevant criteria for punitive damages. But even in the absence of such instructions, untrained citizens have strong intuitions about the role of foreseeability and intent in judgments of punitiveness and blameworthiness. 19 Explicit risk analyses are bound to raise suspicion under an overly literal application of these criteria.

Clearly, defense counsel would need to explain at trial why explicit risk analyses ought to reverse the simple "foreseeable and intentional implies blameworthiness" intuition. It is an open question whether that line of argument would be persuasive, but I'm skeptical. Even among experts, the normative status of benefit-cost analysis has long been disputed, only gradually winning converts. ${ }^{20}$ A great many of my students-even Masters in Public Policy candidates with several years of government experience under their belts-display visceral discomfort when confronted with expert analyses of the economic valuation of human life.21 Many students roll their eyes, shake their heads, or scowl. When asked to explain, they struggle to verbalize their feelings; they find it distasteful to place a value on human life, but they can't say why, and most acknowledge the need for policy analysts to do so.

Viscusi is well aware of this reaction, noting in his essay that "[p]eople may be averse to explicitly balancing money against human lives. Money and lives might be considered incommensurable."22 Several scholars have offered theoretical accounts of this discomfort.23 The most psychologically

19. For evidence of the pervasive role of responsibility in lay judgement across many social domains, see BERNARD WEINER, JUDGMENTS OF RESPONSIBILITY: A FOUNDATION FOR A THEORY OF SOCIAL CONDUCT (1995). For an empirical examination of lay intuitions about foreseeability and intent in judging criminal responsibility, see PAUL H. ROBINSON \& JOHN M. DARLEY, JUSTICE, LIABILITY, AND BLAME: COMMUNITY VIEWS AND THE CRIMINAL LAW (1995).

20. For a general discussion of moral philosophical objections to cost-benefit analysis, see Steven Kelman, Cost-Benefit Analysis: An Ethical Critique, Regulation, Jan.-Feb. 1981, at 33. See generally K.S. SHRADER-FRECHETTE, RISK AND RATIONALITY: PHILOSOPHICAL FOUNDATIONS FOR POPULIST REFORMS (Berkeley: Univ. of Cal. Press 1991); Paul Slovic, Trust, Emotion, Sex, Politics, and Science: Surveying the Risk-Assessment Battlefield, 19 RISK ANALYSIS 689 (1999).

21. Viscusi is a leader in this field. See generally W. KIP VISCUSI, FATAL TRADEOFFS: PUBLIC AND PRIVATE RESPONSIBILITIES FOR RISK (1992).

22. Viscusi, supra note 1 , at 587.

23. See generally GUIDO CALABRESI \& PHILIP BOBBITT, TRAGIC CHOICES (1978); JON Elster, LOCAL JUSTICE: HOW INSTITUTIONS Allocate SCARCE GOODS AND NECESSARY 
sophisticated analysis is the "taboo trade-offs" theory of Alan Page Fiske and Phil Tetlock, ${ }^{24}$ which integrates Fiske's theory of relational models ${ }^{25}$ with Tetlock's work on the psychology of value tradeoffs. 26 Fiske's theory contends that social relations in all societies are governed by various combinations of four fundamental psychological templates: We sometimes categorize individuals and treat category members identically (communal sharing), we sometimes treat individuals by their rank within a group (authority ranking), we sometimes keep score of outcomes and strive to equalize them (equality matching), and we sometimes value outcomes on an absolute metric and make tradeoffs among them (market pricing). 27 Each template has its own rules of appropriate conduct, its own norms of distributive fairness, and most crucially, its own consensually agreed upon domains of operation in a community's life. Fiske's model fits a considerable body of sociological and anthropological evidence, and it has fared well in more exacting psychometric analyses and social-cognitive laboratory experiments.

Fiske and Tetlock offer several lines of argument that seem to anticipate Viscusi's results. They argue that "[c]ost-benefit analysis ignores and usually does violence to normative distinctions that people value as ends in themselves." 28 They explain that "[a]cknowledging that one is prepared to cross boundaries between relational models implies a lack of respect for foundational values of the social order. Love, life and loyalty are generally held to be priceless." 29 Importantly, Fiske and Tetlock themselves appear to endorse Viscusi's arguments regarding the normative value of formal risk analysis; they recognize that "taboo tradeoffs are unavoidable. ... In practice, there is a limit to the dollars we will spend to enhance our own personal safety at the workplace or in cars or airplanes, and we will certainly spend less for the safety of others." 30 But they argue that attempts to apply market pricing to the domain of human life will inevitably encounter resistance: "It is gauche, embarrassing, or offensive to make explicit trade-offs among the concurrently operative relational modes." 31 The implication is that jurors

BURDENS (1992); MICHAEl WALTZER, SPHERES OF JUSTICE: A DEFENSE OF PLURALISM AND EQUALITY (1983).

24. Alan Page Fiske \& Philip E. Tetlock, Taboo Trade-offs: Reactions to Transactions that Transgress the Spheres of Justice, 18 POL. PSYCHOL. 255 (1997).

25. See Alan Page Fiske, The Four Elementary Forms of Sociality: Framework For a Unified Theory of Social Relations, 99 PSYCHOL. REV. 689 (1992) (describing the four fundamental psychological models, the combination of which is the basis for human life).

26. See Philip E. Tetlock, Randall R. Peterson \& Jennifer Lemer, Revising the Value Pluralism Model: Incorporating Social Content and Context Postulates, in THE PSYCHOLOGY OF VALUES: THE ONTARIO SYMPOSIUM 25 (C. Seligman, J. Olson \& M. Zanna eds., 1996).

27. See Fiske, supra note 25 , at 693-708.

28. Fiske \& Tetlock, supra note 24 , at 294.

29. Id. at 290.

30. Id.

31. Id. at 273. 
may object less to their own valuation of safety because it is tacit, unlike the corporation's blatant acknowledgment of this taboo tradeoff. 32

From this perspective, jurors might indeed be susceptible to hindsight biases or a misunderstanding of actual versus statistical deaths, but such effects are unnecessary to explain Viscusi's results. Jurors can be expected to react with dismay to market pricing applied to human life, and they may express their distaste monetarily through increased punitive damages. Most students of public policy analysis gradually overcome this reaction, so perhaps jurors could be persuaded to do so as well, especially if their own consumer tradeoffs between price and safety were made salient. But such a challenging argumentation and persuasion process would be difficult to achieve even in a lengthy trial, much less in a brief simulation.

There is a more radical interpretation. Perhaps Fiske's relational models are indeed driving Viscusi's results, but in a purely cognitive rather than affective manner. Irrespective of any visceral aversion, it could be that the risk analysis evidence simply makes market pricing more salient as the applicable model for the task at hand, leading jurors to conclude that, if the defendant thinks in dollar terms, the mere shame of sanctioning won't be sufficient; the defendant is best deterred using the dollar metric.

\section{LEGAL POLICY IMPLICATIONS}

Whatever the correct interpretation, Viscusi's data on their own are clearly too modest to support his sweeping call to either remove punitive damages judgments from the jury or eliminate punitive damages altogether. Normatively, his arguments about optimal deterrence are more compelling for compensatory damages than for punitive damages, which can serve retributive as well as deterrent functions. ${ }^{33}$ And behaviorally, it isn't clear whether the reforms that seem most feasible would serve their intended purpose. Placing a cap on punitive awards can have unintended consequences; e.g., by providing a convenient judgmental anchor, caps can actually raise small awards. 34 If jurors are prevented altogether from awarding punitive damages, it is likely that they will "hydraulically" inflate non-economic

32. This notion is reminiscent of Tribe's argument that quantified standards of proof are undesirable because the explicit acknowledgment of error rates might delegitimize the system. See Lawrence H. Tribe, Trial by Mathematics: Precision and Ritual in the Legal Process, 84 HARV. L. REV. 1329, 1375-76 (1971).

33. See Lempert, supra note 13, at 872 ("[D]eterrence is not the sole or even the primary justification for punitive damages. Indeed, since a finding of negligence or some other wrongful act must precede an award of punitive damages, deterrence-as opposed to the perceived good of punishing immoral behavior-is probably a less important justification for punitive damages than it is for most criminal punishment.").

34. Jennifer K. Robbennolt \& Christina A. Studebaker, Anchoring in the Courtroom: The Effects of Caps on Punitive Damages, 23 LAW \& HUM. BEHAV. 353, 355-56 (1999). 
compensatory damages instead, though the net effect is likely to be a reduction in total award. ${ }^{35}$ And it has not yet been established that judges are less susceptible to hindsight biases or the effects Viscusi documents in this study. 36

Viscusi's title, "Corporate Risk Analysis: A Reckless Act?" is a clever double entendre, but even if his findings accurately describe the effects of corporate risk analyses on trial verdicts, he hasn't yet demonstrated that corporations are worse off when they conduct such analyses. As Viscusi surely realizes, what matters is not the effect on trial verdicts but rather the effect on the overall expected value of conducting such analyses. That expected value will reflect trial outcomes, but it will also likely reflect settlement outcomes (which are much more common) and the marketing and sales of new (safer vs. cheaper) vehicles.

In conclusion, I find Viscusi's results persuasive, but their interpretation remains an open question, and an important one. Identifying the right explanation matters because we don't know whether Viscusi has identified a narrow cognitive error in juror reasoning, or whether his findings reflect a broad gap separating lay moral intuition and contemporary economic theory-with contemporary tort doctrine falling awkwardly in between.

35. For an empirical demonstration, see Michelle Chernikoff Anderson \& Robert J. MacCoun, Goal Conflict in Juror Assessments of Compensatory and Punitive Damages, 23 LAW \& HUM. BEHAV. 313, 315-16 (1999).

36. See notes 8-13 supra and accompanying text. 